\title{
PENERAPAN MODEL TEAMS GAMES TOURNAMENTS (TGT) DILENGKAPI DENGAN MEDIA INDEX CARD MATCH UNTUK MENINGKATKAN KEMAMPUAN MEMORI DAN PRESTASI BELAJAR SISWA PADA MATERI KOLOID KELAS XI IPA SEMESTER GENAP SMAN 3 BOYOLALI TAHUN PELAJARAN 2016/2017
}

\author{
Putri Fitriana Rahmani ${ }^{1, *}$, Sri Yamtinah ${ }^{1}$, Bakti Mulyani ${ }^{1}$, dan Paerah ${ }^{2}$ \\ ${ }^{1}$ Program Studi Pendidikan Kimia, FKIP, Universitas Sebelas Maret, Surakarta, Indonesia \\ 2SMA Negeri 3 Boyolali, Boyolali, Indonesia
}

*Keperluan korespodensi, telp :085799143343, email : putrifitriana95@gmail.com

\begin{abstract}
ABSTRAK
Penelitian ini bertujuan untuk meningkatkan: (1) kemampuan memori dan (2) prestasi belajar kimia siswa kelas XI IPA 2 SMAN 3 Boyolali tahun pelajaran 2016/2017 melalui penerapan pembelajaran TGT ( Teams Games Tournaments) dengan bantuan Index Card Match pada materi koloid. Penelitian ini merupakan Penelitian Tindakan Kelas (PTK) yang dilakukan dalam dua siklus. Setiap siklus terdapat empat tahapan, yaitu perencanaan, pelaksanaan, observasi, dan refleksi. Subjek penelitian adalah siswa kelas XI IPA 2 SMAN 3 Boyolali tahun pelajaran 2016/2017. Teknik pengumpulan data melalui observasi, wawancara, kajian dokumen, angket dan tes, sedangkan teknik analisis yang digunakan dalam penelitian ini adalah deskriptif. Berdasarkan hasil penelitian dapat disimpulkan bahwa penerapan model pembelajaran Teams Games Tournament (TGT) dilengkapi dengan Index Card Match (ICM) dapat meningkatkan: (1) kemampuan memori siswa pada materi koloid. Pada prasiklus, ketercapaian kemampuan memori sebesar $12,5 \%$ dan meningkat menjadi $43,7 \%$ pada siklus I dan $78,1 \%$ pada siklus II, (2) prestasi belajar siswa kelas XI IPA 2 pada materi koloid di SMAN 3 Boyolali tahun pelajaran 2016/2017. Berdasarkan hasil tes siklus I ketercapaian aspek pengetahuan pada siklus I sebesar 40,6\% dan meningkat menjadi $84,4 \%$ pada siklus II. Ketercapaian aspek afektif siswa sebesar $87,5 \%$ dan meningkat menjadi $93,75 \%$ pada siklus II. Ketercapaian aspek psikomotor sebesar $91 \%$.
\end{abstract}

Kata Kunci : Teams Games Tournament (TGT), Index Card Match (ICM), Kemampuan Memori, Prestasi Belajar, Koloid

\section{PENDAHULUAN}

Pembelajaran merupakan kegiatan yang dilakukan antara guru dan siswa dimana guru berperan untuk mengajar dan membimbing anak didik menuju proses pendewasaan [1]. Pembelajaran dilakukan untuk mempelajari berbagai ilmu pengetahuan, salah satunya adalah IImu Pengetahuan Alam (IPA). IPA berkaitan dengan cara mencari tahu tentang alam secara sistematis sehingga IPA bukan hanya penguasaan kumpulan pengetahuan yang berupa fakta, konsep maupun prinsip tetapi juga merupakan suatu proses penemuan. Pembelajaran IPA diharapkan dapat menjadi sarana bagi siswa untuk memperoleh pengalaman langsung dalam mempelajari dan memahami alam sekitar secara ilmiah, sehingga siswa dapat terlibat dalam proses penemuan yang diharapkan dapat memperdalam pemahaman siswa

IImu kimia merupakan cabang dari ilmu pengetahuan alam yang mempelajari kajian tentang struktur, komposisi, sifat dan perubahan materi serta energi yang menyertai perubahan tersebut [2]. Kimia merupakan ilmu yang berisi konsep-konsep yang sebagian besar bersifat abstrak, kompleks dan terdapat unsur matematis. Karakteristik kimia yang abstrak mengakibatkan dalam pembelajarannya perlu metode 
yang tepat untuk mengantarkan konsep abstrak tersebut kepada siswa. Melaksanakan pembelajaran kimia dengan melibatkan siswa secara langsung dalam proses pembelajaran diharapkan dapat meningkatkan pemahaman siswa terhadap konsep kimia.

IImu kimia memiliki tingkat kesulitan yang tinggi karena di dalam kimia terdapat tiga domain dasar yang harus dikuasai. Pendekatan baru untuk belajar dan mengajar kimia perlu mencakup tiga domain dasar yakni makro, mikro dan simbolik [3]. Untuk dapat mempelajari ilmu kimia secara utuh harus dapat mempelajari dan dapat menghubungkan ketiga domain tersebut secara tepat. Selain itu, kimia erat kaitannya dengan konsep yang bersifat abstrak yang membutuhkan penalaran ilmiah dan pemahaman tinggi. Salah satu materi kimia yang mengandung konsep abstrak adalah koloid. Kesulitan belajar pada materi koloid dialami oleh siswa siswi SMA Negeri 3 Boyolali yang ditunjukkan dengan hasil penilaian terhadap materi koloid pada tiga tahun terakhir yang masih berada di bawah batas ketuntasan minimum.

Berdasarkan wawancara guru dan observasi di SMAN 3 Boyolali, dapat diketahui bahwa siswa cenderung menghafalkan materi koloid karena karakteristik materi koloid yang berisi teori dan konsep tetapi siswa kurang berusaha untuk memahami. Pembelajaran kimia dilaksanakan menggunakan metode konvensional yaitu ceramah yang mengakibatkan interaksi antara guru dan siswa yang terjadi di dalam kelas hanya satu arah yaitu interaksi berasal dari pihak guru. Siswa cenderung pasif pada saat penyampaian materi dan diskusi kelompok dan kurang responsif terhadap pertanyaan yang diajukan oleh guru. Siswa belum berperan aktif dan terlibat langsung dalam pembelajaran. Hal tersebut menjadikan siswa kurang antusias dan tidak memperhatikan ketika proses pembelajaran sehingga mengakibatkan siswa tidak menyerap, mengingat dan memahami materi pelajaran yang diberikan dengan maksimal.
Prestasi belajar siswa SMA Negeri 3 Boyolali pada mata pelajaran kimia masih tergolong rendah, hal ini dapat terlihat dari nilai rata-rata Ujian Akhir Semester (UAS) ganjil pada kelas XI tahun pelajaran 2016/2017 adalah 71 yang mana belum mencapai kriteria ketuntasan minimum yang ditetapkan yaitu 75 . Data nilai UAS ganjl mata pelajaran kimia tahun pelajaran 2016/2017 dapat dilihat pada tabel 1.

Tabel 1. Hasil Nilai UAS Kimia XI IPA Semester Ganjil Tahun Pelajaran 2016/2017

\begin{tabular}{lc}
\hline Kelas & Rata-Rata Nilai \\
\hline XI IPA 1 & 76,125 \\
XI IPA 2 & 65,718 \\
XI IPA 3 & 72,483 \\
XI IPA 4 & 73 \\
XI IPA 5 & 66,843 \\
XI IPA 6 & 72 \\
\hline
\end{tabular}

Berdasarkan data pada tabel 1, dapat diketahui bahwa terdapat kelas yang memiliki nilai rata-rata paling rendah dibandingkan dengan kelas lain yaitu kelas XI IPA 2 yang memiliki ratarata kelas 65,7 . Berdasarkan data nilai tersebut, dapat disimpulkan bahwa prestasi mata pelajaran kimia kelas XI IPA 2 SMA Negeri 3 Boyolali masih rendah.

Berdasarkan uraian di atas dapat diidentifikasi beberapa permasalahan yang terjadi, yaitu prestasi belajar kimia siswa pada materi koloid masih tergolong rendah, interaksi sosial pada saat pembelajaran hanya satu arah, keterlibatan siswa yang masih rendah pada proses pembelajaran dan kecenderungan siswa yang menghafalkan materi pelajaran yang tidak disertai dengan pemahaman. Beberapa permasalahan yang dialami dalam proses pembelajaran tersebut memerlukan solusi pemecahan masalahnya.

Materi koloid merupakan materi yang bersifat abstrak tetapi terdapat beberapa konsep yang bersifat konkret yang banyak dijumpai di kehidupan. Materi koloid berisi teori, konsep dan tidak mengandung unsur matematis, 
sehingga membutuhkan pemahaman dan kemampuan memori untuk mempelajari dan memahami materi koloid. Kemampuan memori merupakan kemampuan untuk memasukkan (learning), menyimpan (retention), dan memunculkan kembali (remembering) hal-hal yang lampau [4]. Karakteristik materi koloid tersebut menjadikan perlunya penggunaan model pembelajaran dan media pembelajaran yang dapat membantu siswa agar tidak jenuh dalam proses pembelajaran sehingga dapat meningkatkan pemahaman siswa terhadap materi koloid.

Prasiklus untuk tes kemampuan memori siswa yang dilakukan kepada siswa kelas XI IPA 2 mendapatkan hasil bahwa siswa yang tergolong memiliki kemampuan memori yang tinggi adalah $12,5 \%$ atau sebanyak 4 siswa dari 32 siswa. Berdasarkan hasil prasiklus tersebut, maka diperlukan suatu tindakan untuk meningkatkan kemampuan memori siswa.

TGT merupakan model pembelajaran yang efektif dalam meningkatkan prestasi belajar dan memori siswa [5]. Implementasi TGT secara efektif dapat meningkatkan prestasi belajar siswa dan dapat meningkatkan kemampuan sosial siswa serta memperbaiki perilaku siswa dalam pembelajaran [6]. Penerapan model pembelajaran TGT dilengkapi dengan media chem puzzle dapat meningkatkan kemampuan memori siswa [7]. Penerapan model TGT dapat meningkatkan kualitas proses dan hasil belajar siswa [8].

Model pembelajaran TGT merupakan salah satu model pembelajaran kooperatif, yang mana dalam melakukan pembelajaran siswa bekerja dalam kelompok untuk saling membantu satu sama lain dalam mempelajari materi pelajaran. Pembelajaran dengan menggunakan model TGT memiliki sintak pembelajaran memperhatikan penjelasan guru, berdiskusi kelompok, memecahkan masalah, melakukan permainan dan melakukan turnamen [9]. Penerapan TGT dapat memungkin-kan siswa untuk belajar dalam suasana yang menyenangkan, melatih kerjasama siswa, tanggung jawab, keterlibatan belajar dan dapat memotivasi siswa untuk lebih memahami materi pelajaran sehingga dapat bersaing untuk memenangkan turnamen.

Penerapan model TGT dilengkapi dengan penggunaan media pembelajaran untuk memberikan perangsang bagi peserta didik supaya terjadi proses belajar dan dapat membantu proses pembelajaran agar tujuan pembelajaran dapat tercapai. Penggunaan media Index Card Match pada model pembelajaran TPS (Think Pair Share) efektif meningkatkan prestasi belajar [10].

Index Card Match (ICM) merupakan cara yang menyenangkan dan dapat merangsang keaktifan belajar siswa dalam meninjau ulang materi pembelajaran yang dilakukan dengan memberikan kesempatan terhadap peserta didik untuk berpasangan dan melakukan permainan dengan teman satu kelas [11]. Penggunaan media pembelajaran ICM yang diintegrasikan dalam permainan pada model TGT diharapkan dapat melatih kemampuan memori siswa kaitannya dengan kemampuan untuk memasukkan/menerima, menyimpan dan memunculkan kembali informasi yang didapatkan pada saat proses pembelajaran berlangsung.

Berdasarkan uraian di atas, maka perlu dilakukan penerapan model pembelajaran Teams Games Tournaments (TGT) dilengkapi dengan media Index Card Match untuk meningkatkan kemampuan memori dan prestasi belajar siswa pada materi koloid kelas XI IPA 2 semester genap SMAN 3 Boyolali tahun pelajaran 2016/2017.

\section{METODE PENELITIAN}

Penelitian ini merupakan Penelitian Tindakan Kelas (PTK) yang dilaksanakan dalam dua siklus. Setiap siklusnya terdapat empat tahapan, yaitu perencanaan, pelaksanaan, observasi, dan refleksi [12]. Subjek penelitian adalah siswa kelas XI IPA 2 SMAN Boyolali tahun pelajaran 2016/2017. Pemilihan subjek dalam penelitian ini didasarkan pada hasil observasi yang dilakukan pada saat prasiklus, dimana subjek yang dipilih tersebut teridentifikasi mempunyai 
permasalahan dalam pembelajaran yaitu kemampuan memori dan prestasi belajar yang rendah.

Data yang dikumpulkan meliputi data tentang keadaan siswa yang berupa data kualitatif dan kuantitatif. Data kualitatif diperoleh dari hasil observasi, angket afektif, dan wawancara. Data kuantitatif didapat dari hasil penilaian prestasi belajar siswa pada materi koloid yang meliputi aspek kognitif, afektif dan psikomotor pada siklus I, sedangkan pada siklus II hanya dilakukan penilaian pada kognitif dan afektif.

Teknik analisis data pada penelitian ini menggunakan analisis deskriptif. Analisis data menggunakan tiga tahap yaitu reduksi data, penyajian data, dan penarikan kesimpulan dan verifikasi [13].

Teknik triangulasi juga digunakan untuk memeriksa keabsahan data yang memanfaatkan sesuatu yang lain [12]. Dalam penelitian ini, dilakukan teknik triangulasi metode yang dilakukan dengan cara membandingkan data dengan cara/metode yang berbeda yaitu melalui observasi, angket dan wawancara.

\section{HASIL DAN PEMBAHASAN}

Penelitian tindakan kelas ini bertujuan untuk meningkatkan kemampuan memori dan prestasi belajar siswa kelas XI IPA 2 SMAN Boyolali pada materi koloid dengan menerapkan model pembelajaran TGT dilengkapi media ICM. Kemampuan memori siswa dalam pembelajaran meliputi kemampuan siswa dalam menerima, menyimpan dan memunculkan kembali informasi terkait dengan materi koloid. Prestasi belajar yang diukur meliputi aspek kognitif, afektif dan psikomotor. Penerapan model TGT menjadikan proses pembelajaran berlangsung secara menyenangkan dan dapat meningkatkan keterlibatan siswa.

Hasil prasiklus tes kemampuan memori yang dilakukan di kelas XI IPA 2 SMAN 3 Boyolali tahun pelajaran 2016/2017 dapat dilihat pada tabel 2.
Tabel 2. Hasil Prasiklus Kemampuan Memori

\begin{tabular}{lc}
\hline Kategori & Ketercapaian $(\%)$ \\
\hline Tinggi & 12,5 \\
Sedang & 37,5 \\
Rendah & 50 \\
\hline
\end{tabular}

Berdasarkan tabel 2 dapat diketahui bahwa dari 32 siswa, sebanyak 16 siswa (50\%) mempunyai kemampuan memori kategori rendah. Dari hasil prasiklus tersebut menunjukkan bahwa kemampuan memori siswa masih rendah.

\section{Siklus I}

Pada tahap perencanaan siklus I dilakukan penyusunan Rencana Pelaksanaan Pembelajaran (RPP) yang disusun berdasarkan silabus, instrumen penilaian kemampuan memori dan instrumen penilaian prestasi belajar. Perincian pembelajaran materi koloid dalam penelitian ini terdiri dari tiga kali pertemuan (6 JP) dengan alokasi $6 \times 45$ menit untuk penyampaian materi dan satu kali pertemuan (1 JP) 2 x 45 menit untuk kegiatan evaluasi siklus $\mathrm{I}$.

Tahap pelaksanaan siklus I pertemuan 1 dan 2 dilakukan diskusi kelompok yang dilanjutkan dengan pelaksanaan permainan. Pembelajaran diawali dengan guru memberikan apersepsi, menjelaskan tujuan serta memberikan motivasi kepada siswa, lalu guru menjelaskan garis besar materi yang akan dipelajari dan membentuk kelompok belajar secara heterogen. Guru memberikan permasalahan dalam bentuk soal diskusi untuk diselesaikan siswa secara berkelompok. Setelah selesai diskusi, siswa diminta untuk mempresentasikan hasil diskusinya.

Setelah diskusi selesai, dilakukan permainan antar kelompok dengan bantuan media ICM. Permainan dimulai dengan guru menjelaskan peraturan, kemudian guru menempelkan kartu soal di depan kelas. Kelompok siswa maju ke depan kelas secara bergantian untuk mencocokkan kartu jawaban dengan kartu pertanyaan. Setelah semua kelompok maju maka guru dan siswa bersama sama mengecek hasil 
permainan. Pembelajaran dilanjutkan dengan konfirmasi hasil diskusi dan permainan oleh guru serta pemberian penghargaan terhadap kelompok yang memiliki skor tertinggi. Pembelajaran diakhiri dengan guru membimbing siswa menyimpulkan hasil pembelajaran. Pada pertemuan 3, tahapan pembelajaran sama dengan pertemuan sebelumnya tetapi sebelum diskusi dilakukan praktikum tentang cara pembuatan koloid. Pada pertemu-an terakhir, dilaksanakan evaluasi siklus I yang meliputi penilaian aspek kognitif, angket afektif dan tes kemampuan memori.

Hasil penilaian tindakan selama siklus I dirangkum dalam Tabel 3.

Tabel 3. Rangkuman Hasil Penilaian Siklus I

\begin{tabular}{lccc}
\hline $\begin{array}{l}\text { Aspek yang } \\
\text { dinilai }\end{array}$ & $\begin{array}{c}\text { Capaian } \\
(\%)\end{array}$ & $\begin{array}{c}\text { Target } \\
(\%)\end{array}$ & Kriteria* $^{*}$ \\
\hline Kognitif & 56,25 & 70 & BT \\
Afektif & 87,5 & 70 & T \\
Psikomotor & 91 & 70 & T \\
Memori & 43,7 & 70 & BT \\
\hline${ }^{*}$ Kriteria : T (Tercapai), BT (Belum Tercapai)
\end{tabular}

Berdasarkan Tabel 3, dapat terlihat bahwa aspek yang belum mencapai angka target ketuntasan adalah aspek kognitif dan aspek memori. Ketuntasan aspek kognitif sebesar $56,25 \%$ atau sebanyak 13 siswa belum mencapai ketuntasan. Berdasarkan persentase ketercapaian tiap indikator kompetensi, masih ada dua dari sembilan indikator yang belum men-capai target ketuntasan yaitu indikator kompetensi menjelaskan koloid liofil dan liofob serta menjelaskan proses pembuatan koloid. Berdasarkan analisis jawaban siswa dan wawancara, ketidaktuntasan indikator tersebut dikarenakan siswa mengalami kesulitan dalam mem-bedakan jenis koloid yang tergolong liofob atau liofil, kemudian siswa kesulitan dalam menentukan cara pembuatan dari suatu koloid karena siswa kurang memahami konsep dari berbagai cara pembuatan koloid. Hal tersebut disebabkan karena pada saat pembelajaran mengenai cara pembuatan koloid dilakukan dengan praktikum, dimana hanya sebagian cara yang dibahas saat pembelajaran berlangsung.

Apabila dilihat lebih lanjut pada hasil tes kognitif dapat diketahui bahwa terdapat indikator soal yang tidak mencapai ketuntasan tetapi tuntas pada indikator kompetensi yaitu pada soal nomor 19, 2 dan 10. Pada soal nomor 19 diberikan beberapa contoh koloid kemudian siswa diharapkan dapat menggolongkan contoh yang termasuk sol cair, namun siswa terlihat terkecoh dengan pilihan jawaban yang terlihat dari sebagian siswa memilih jawaban yang koloid tersebut tergolong dalam emulsi padat. Berdasarkan hal tersebut dapat diketahui bahwa siswa mengalami kesulitan dalam mem-bedakan sol cair dengan emulsi padat. Pada soal nomor 2 dan 10 merupakan soal yang memiliki indikator kompetensi yang sama yaitu mendeskripsikan peranan koloid. Ketidaktuntasan pada kedua butir soal tersebut disebabkan karena siswa kesulitan dalam menentukan peranan yang tepat pada masing-masing sifat koloid yang disebabkan karena siswa kurang memahami konsep dari sifat-sifat koloid.

Capaian aspek memori pada siklus I sebesar 43,7\% yang menunjukkan belum tercapainya target yang ditetapkan, namun hasil kemampan memori siklus I telah mengalami kenaikan dibandingkan dengan hasil prasiklus. Untuk hasil penilaian aspek afektif dan psikomotor sudah mencapai target yang ditentukan, yakni dengan ketercapaian sebesar $87,5 \%$ untuk aspek afektif dan $91 \%$ untuk aspek psikomotor. Pada aspek afektif, tetap dilakukan penilaian pada siklus II dengan tujuan untuk mengetahui ada atau tidaknya peningkatan setelah dilakukan tindakan pada siklus II.

Berdasarkan pembelajaran yang dilakukan pada siklus I, guru terlihat sedikit bingung dengan model pembelajaran dan permainan ICM yang diterapkan, sehingga diperlukan pemahaman lebih lanjut terkait dengan teknis pelaksanaan pembelajaran agar pembelajaran berlangsung lancar dan lebih efektif. Hasil yang telah diperoleh pada siklus I menunjukkan masih terdapat aspek yang belum mencapai 
target yaitu aspek kognitif dan memori. Oleh karena itu, perlu dilaksanakan siklus II yang diharapkan dapat memperbaiki proses pembelajaran pada siklus I sehingga target yang sudah ditentukan dapat tercapai.

\section{Siklus II}

Pada pelaksanaan siklus II ini lebih difokuskan untuk perbaikan terhadap kendala-kendala yang muncul pada siklus I. Materi yang diberikan juga fokus pada indikator-indikator yang belum mencapai ketuntasan yaitu menjelaskan koloid liofil dan liofob serta menjelaskan proses pembuatan koloid. Pemberian evaluasi juga terbatas pada soal dengan indikator-indikator yang belum tuntas saja.

Guru lebih memfokuskan pada siswa yang hasil evaluasi siklus I mendapatkan nilai yang tergolong rendah dibandingkan teman-temannya untuk perbaikan pada siklus II. Kelompok diskusi pada siklus II ini dibagi berdasarkan nilai yang telah didapat siswa pada evaluasi siklus I. Hal ini dilakukan agar siswa dengan kemampuan akademik yang lebih tinggi dapat membantu siswa dengan kemampuan yang masih rendah.

Pada tahap perencanaan siklus II, peneliti membuat instrumen pembelajaran berupa RPP. Sedangkan untuk instrumen penilaian, peneliti hanya menyusun instrumen untuk tes aspek kognitif siklus II. Sedangkan untuk angket aspek afektif dan kemampuan memori, instrumen yang digunakan sama dengan siklus I.

Pelaksanaan tindakan siklus II dilaksanakan dalam satu kali pertemuan pertemuan ( $2 \times 45$ menit) dengan alokasi waktu $1 \times 45$ menit pertama untuk proses pembelajaran dan $1 \times 45$ menit kedua untuk evaluasi siklus II. Tindakan pada siklus II difokuskan kepada tiga aspek yaitu prestasi belajar aspek kognitif, prestasi belajar aspek afektif, dan kemampuan memori siswa. Proses pembelajaran difokuskan pada indikator kompetensi yang belum mencapai target ketuntasan, yakni menjelaskan koloid liofil dan liofob serta menjelaskan proses pembuatan koloid. Pada jam pelajaran pertama, guru memberikan permasalahan berupa soal diskusi agar siswa lebih memahami materi yang diajarkan, setelah itu kelompok yang sudah selesai diminta maju untuk mengerjakan soal di depan dengan kelompok lain bisa bertanya terkait hal yang belum dimengerti. Proses pembelajaran selanjutnya adalah melakukan permainan pembelajaran menggunakan media ICM terkait dengan materi yang disampaikan. Guru memberikan konfirmasi mengenai hasil diskusi dan permainan dan membimbing siswa membuat kesimpulan di akhir pembelajaran. Pada jam pelajaran berikutnya dilaksanakan evaluasi siklus II yang terdiri atas tes aspek kognitif dan tes kemampuan memori. Adapun hasil penilaian tindakan selama siklus II dirangkum dalam Tabel 4.

Tabel 4. Rangkuman Hasil Penilaian Siklus II

\begin{tabular}{lccc}
\hline $\begin{array}{c}\text { Aspek } \\
\text { yang dinilai }\end{array}$ & $\begin{array}{c}\text { Capaian } \\
(\%)\end{array}$ & $\begin{array}{c}\text { Target } \\
(\%)\end{array}$ & Kriteria* $^{*}$ \\
\hline Kognitif & 84,4 & 70 & $\mathrm{~T}$ \\
Afektif & 93,75 & 70 & $\mathrm{~T}$ \\
Memori & 78,1 & 70 & $\mathrm{~T}$ \\
\hline
\end{tabular}

${ }^{*}$ Kriteria : T (Tercapai), BT (Belum Tercapai)

Berdasarkan data yang diperoleh pada siklus II, terlihat semua aspek meliputi aspek kognitif, afektif dan kemampuan memori mengalami peningkatan capaian dari siklus I dan sudah melampaui target sehingga penelitian di akhiri pada siklus II. Penilaian terhadap aspek kognitif pada siklus II lebih baik jika dilakukan dengan mengulang materi pada indikator soal siklus I yang belum mencapai ketuntasan untuk menge-tahui kesulitan belajar siswa dengan lebih spesifik.

\section{Perbandingan Hasil 2 Siklus}

Perbandingan hasil tindakan antar siklus ini bertujuan untuk mengetahui peningkatan yang terjadi selama tindakan siklus I dan siklus II. Berdasarkan hasil analisis penilaian tindakan siklus I dan siklus II, diperoleh peningkatan hasil dari aspek kognitif, afektif dan kemampuan memori. 


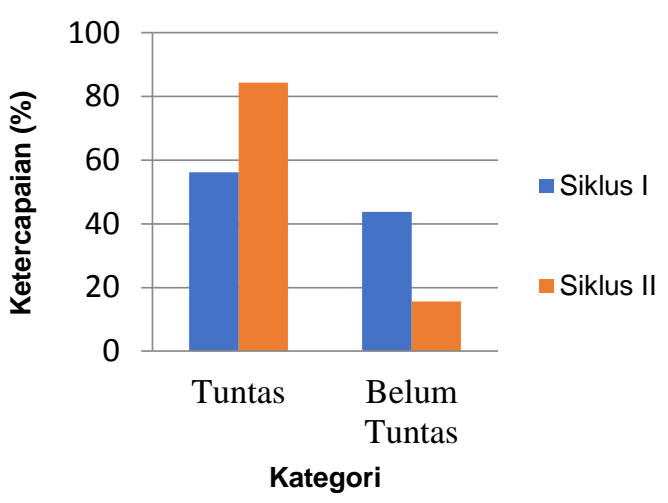

Gambar 1. Histogram Perbandingan Persentase Ketuntasan Aspek Kognitif Siswa Siklus I dan II

Pada siklus I diperoleh ketuntasan aspek kognitif sebesar $56,28 \%$ atau sebanyak 18 siswa tuntas. Hasil ini belum mencapai target yang ditentukan sehingga pembelajaran dilanjutkan ke siklus II untuk meningkatkan hasil aspek kognitif. Hasil tes siklus II menunjukkan $84,4 \%$ atau sebanyak 27 siswa telah mencapai kriteria ketuntasan minimum. Berdasarkan hasil tersebut dapat disimpulkan terdapat peningkatan ketuntasan belajar siswa dari siklus I ke siklus II sebesar $28,15 \%$.

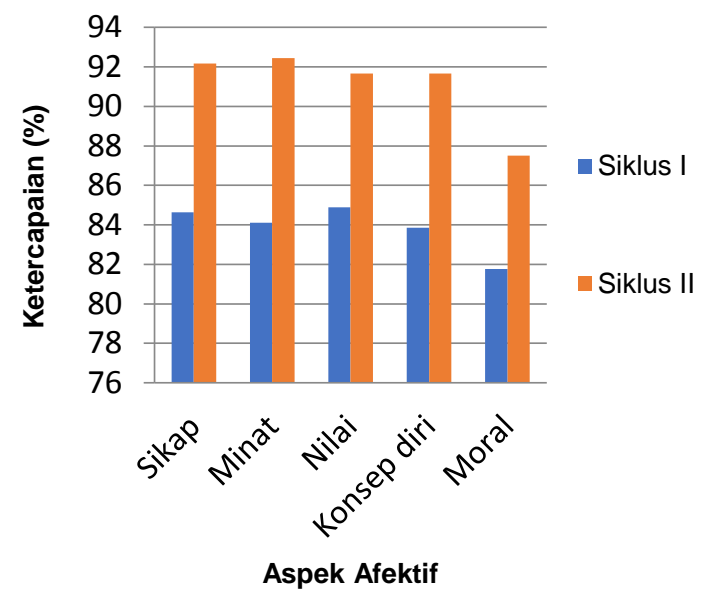

Gambar 2. Histogram Perbandingan Persentase Ketercapaian Aspek Kognitif Siswa Siklus I dan II

Berdasarkan Gambar 2, dapat dilihat bahwa terdapat peningkatan hasil belajar siswa pada masing-masing aspek afektif. Pada siklus I ketercapaian aspek afektif sebesar $87,5 \%$ dan dinyatakan telah mencapai target yang ditentukan. Pengukuran terhadap aspek afektif tetap dilakukan pada siklus II untuk melihat pengaruh tindakan terhadap aspek afektif. Hasil capaian aspek afektif pada siklus II mengalami peningkatan sebesar $6,25 \%$ meningkat menjadi $93,75 \%$. Hal ini menunjukkan bahwa pemberian tindakan pada siklus II ternyata dapat meningkatkan prestasi belajar siswa pada aspek afektif menjadi lebih baik.

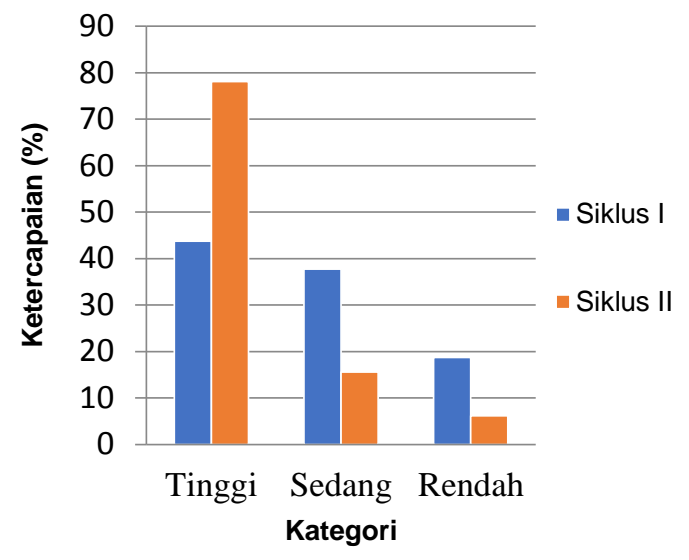

Gambar 3. Histogram Perbandingan Persentase Ketercapaian Kemampuan Memori Siswa Siklus I dan II

bahwa persentase ketercapaian kemampuan memori siswa dengan kategori tinggi mengalami peningkatan yang signifikan dari siklus I ke siklus II. Peningkatan tersebut sejalan dengan penurunan pada kategori sedang dan rendah. Hal ini menunjukkan bahwa pemberian tindakan pada siklus II ternyata dapat meningkatkan kemampuan memori siswa.

Berdasarkan hasil tersebut, penelitian dengan menggunakan model pembelajaran Teams Games Tournaments (TGT) dilengkapi dengan media Index Card Match (ICM) dikatakan berhasil karena pada akhir penelitian semua aspek telah mencapai target yang ditetapkan. Penelitian ini dapat meningkatkan kemampuan memori dan prestasi belajar siswa yang meliputi aspek kognitif, afektif dan psikomotor.

\section{KESIMPULAN}

Berdasarkan hasil penelitian yang telah dilakukan, maka dapat disimpulkan bahwa penerapan model pembelajaran 
Teams Games Tournaments (TGT) dilengkapi media Index Card Match pada materi koloid kelas XI IPA semester genap SMAN 3 Boyolali Tahun Pelajaran 2016/2017 dapat meningkatkan kemampuan memori dan prestasi belajar siswa.

Persentase ketercapaian kemampuan memori siswa pada siklus I sebesar $43,7 \%$ menjadi $78,1 \%$ pada siklus II. Peningkatan prestasi belajar siswa juga terlihat dari hasil prestasi belajar aspek kognitif sebesar $56,25 \%$ pada siklus I dan menjadi $84,4 \%$ pada siklus II. Capaian aspek afektif siklus I sebesar $87,5 \%$ meningkat menjadi 93,75\%. Capaian aspek psikomotor pada siklus I sebesar $91 \%$.

\section{UCAPAN TERIMAKASIH}

Penelitian ini dapat terselenggara dengan baik karena bantuan dari berbagai pihak. Oleh karena itu penulis ingin mengucapkan terimakasih kepada Kepala SMAN 3 Boyolali, Bapak Khaerul Anwar, S.Pd atas izin yang diberikan kepada penulis untuk melakukan penelitian, dan kepada siswa-siswi kelas XI IPA 2 SMAN 3 Boyolali tahun pelajaran 2016/2017 yang telah membantu penulis dalam menyelesaikan penelitian ini.

\section{DAFTAR RUJUKAN}

[1] Suyono \& Hariyanto. (2014). Belajar dan Pembelajaran. Bandung: Remaja Rosdakarya.

[2] Faizi, M. (2013). Ragam Metode Mengajarkan Eksakta pada Murid. Yogyakarta: Familia.

[3] Sirhan, G. (2007). Learning Difficulties in Chemistry: An Overview. Journal of Turkish Science Education, 4(2), 1 - 19.

[4] Walgito, B. (2005). Pengantar Psikologi Umum. Yogyakarta: Andi Offset.
[5] Wyk, M.M.V. (2011). International Journal of School of Social Science, Language, Education and Early Child Development, 26(3), 183-193.

[6] Gonzalez, A., Jennings, D \& Manriquez, L. (2014). International Journal of Engineering Education, 30 (5), 1213-1224.

[7] Pertiwi, Y.H., Masykuri, M., \& Yamtinah, S. (2016). Prosiding Seminar Nasional Pendidikan Sains (SNPS), 349-354.

[8] Fajri, L., Martini, K.S., \& Agung N.C.S. (2012). Jurnal Pendidikan Kimia (JPK), 1 (1), 89-96.

[9] Slavin, R.E. (2008). Psikologi dan Pendidikan (Teori dan Praktik) (Edisi ke- 9, Jilid 2). Terj. Marianto Samosir. Jakarta: PT Indeks Permata Putri Media. (Buku asli diterbitkan 2009).

[10] Nugraha, D.A., Susanti, E., \& Masykuri, M. (2013). Jurnal Pendidikan Kimia (JPK), 2 (4), 174181.

[11] Hamruni. (2012). Strategi Pembelajaran. Yogyakarta: Insan Madani.

[12] Arikunto, S., Suharjono dan Supardi. (2006). Penelitian Tindakan Kelas. Jakarta: Bumi Aksara.

[13] Sugiyono. (2010). Metode Penelitian Pendidikan. Bandung: Penerbit Alfabeta. 